\title{
IDENTIFICATION OF ADULTERANT AND ALCOHOL ROUTE IN BIODIESEL USING MID-INFRARED ABSORPTION SPECTROSCOPY
}

\author{
Maryleide Ventura da Silva \\ Universidade Estadual de Mato Grosso do Sul, Brazil \\ E-mail: maryleide.ventura@gmail.com \\ Sandro Marcio Lima \\ Universidade Estadual de Mato Grosso do Sul, Brazil \\ E-mail: smlima@uems.br \\ Luis Humberto da Cunha Andrade \\ Universidade Estadual de Mato Grosso do Sul, Brazil \\ E-mail: luishca@me.com \\ Euclésio Simionatto \\ Universidade Estadual de Mato Grosso do Sul, Brazil \\ E-mail: euclesio@uems.br \\ Márcio da Silva Figueiredo \\ Universidade Estadual de Mato Grosso do Sul, Brazil \\ E-mail: marciofigueiredo@ufgd.edu.br
}

Submission: 09/03/2013

Revision: 26/09/2013 Accept: 10/10/2013

\section{ABSTRACT}

Mid-infrared absorption spectroscopy was used to analyze soybean oil, ethylic and methylic soybean biodiesel, and blends prepared with soybean oil mixed with biodiesel, in order to evaluate this method as an alternative to assess oil as impurities or adulterant in biodiesel. We also aimed to determine whether the biodiesel was prepared by the ethyl or methyl routes, by inspecting the infrared spectra. The C-O functional groups between 1100 and $1200 \mathrm{~cm}^{-1}$ are different for oil and biodiesel, which allows them to be used to distinguish impurities (residual oil) in biofuel. The peak C-O-C at 1017 $\mathrm{cm}^{-1}$ is characteristic for methylic biodiesel, and the peak O-C-C at $1035 \mathrm{~cm}^{-1}$ for ethylic biodiesel. These vibrational modes can therefore 
INDEPENDENT JOURNAL OF MANAGEMENT \& PRODUCTION (IJM\&P)

http://www.ijmp.jor.br

v. 5, n. 1, October - January 2014.

ISSN: 2236-269X

DOI: 10.14807/ijmp.v5i1.136

be used to indicate the route used to prepare the biofuel. Results indicated that infrared spectroscopy is appropriate for monitoring the quality of biofuel for commercial sale.

Keywords: biodiesel, oil-biodiesel blends, infrared spectroscopy.

\section{INTRODUCTION}

Biodiesel is a fuel derived from renewable energy sources, and has been proposed as an alternative to fossil fuels, mainly due to its environmental benefits (Meher et al. 2006, Nabi et al. 2006, Varun et al. 2013, Silva et al. 2013). It has been marketed in several countries, and in Brazil it is currently sold mixed with up to $8 \%$ diesel. Some studies have indicated that the use of biodiesel will increase within the next few years, making it essential to determine the properties of biodiesel (quality, purity, origin, etc.).

The most common chemical method used to obtain biodiesel is the transesterification process, in which triglyceride molecules are reacted with alcohol molecules in the presence of a catalyst (Silva et al. 2012, Kucek et al. 2007). Because this is a reversible reaction, the conversion from triglyceride to ester is not totally efficient, so that triglycerides are often present as residues in the ester. The ester may also contain residual alcohol molecules and traces of catalyst or glycerol that were not eliminated during the purification process. Thus, the processes of production and purification may result in a biofuel that is likely to cause an engine to deteriorate (Meher et al. 2006, Knothe 2010). For these reasons, the National Agency of Petroleum, Natural Gas and Biofuels (ANP), regulated by the Brazilian Association of Technical Standards (ABNT), established acceptable limits of impurities in biodiesel: the standard indicates that $96.5 \%$ must be ester, i.e., $3.5 \%$ is the limit of all impurities combined (Resolution from the Agência Nacional do Petróleo, Gás Natural e Biocombustíveis (ANP), 2013). This regulation is based on the international standards of the American Society for Testing and Materials (ASTM), the International Organization for Standardization (ISO) and the Comite Européen de Normalisation (CEN). These specifications require efficient technical methods for quality analysis.

The methods most commonly used for monitoring the quality of biofuel in order to detect the presence of adulterants are chromatography and mid-infrared optical 
absorption spectroscopy (Lira et al. 2010, Richard et al. 2011, Jiang et al. 2010). Chromatography is an efficient technique for the analysis of biodiesel; however, it is very expensive and destructive. In contrast, mid-infrared spectroscopy in a detection range of $4000-400 \mathrm{~cm}-1$ is a nondestructive technique and it affords good reproducibility, with very rapid acquisition time and high spectral resolution, requiring a minimum amount of sample for analysis (Meher et al. 2006, Knothe et al. 2005). Mid-infrared spectroscopy has been widely used to analyze biodiesel and diesel blends, mainly because they are sold at gas stations (Aliske et al. 2007, Monteiro et al. 2008, Pimentel et al. 2006, Lira et al. 2010). Some studies have evaluated the efficiency of the transesterification process via mid-infrared spectroscopy (Dubé et al. 2004, Richard et al. 2011). More recently, I. P. Soares and coauthors used the midinfrared spectroscopy combined with chemometric tools for identification of oil as adulterant in biodiesel (Soares et al. 2008). Thus, it is of great importance to the development of biodiesel fuel to use the mid-infrared absorption spectroscopy to detect contaminants, such as soybean oil, that can be originated both from the transesterification process as well as by the contamination purpose.

The present study investigated the potential application of mid-infrared spectroscopy to assess the presence of residual soybean oil in methylic and ethylic biodiesel, and to provide information about the alcohol route used to prepare the biodiesel. This oil is regarded as an impurity and/or adulterant present in biodiesel, since its presence in biodiesel may result either from an incomplete transesterification reaction or from purposeful addition.

\section{EXPERIMENTAL}

\subsection{Preparation of biodiesel and oil-biodiesel blends}

Biodiesel was prepared by using Sadia ${ }^{\circledR}$ refined soybean oil, in a transesterification process with potassium hydroxide $(\mathrm{KOH})$ as catalyst, following two different routes: methylic and ethylic. The molar ratio of alcohol:oil and the quantity of catalyst used in the reaction were, respectively, $16: 1$ with $0.7 \% \mathrm{KOH}$ and $24: 1$ with $0.6 \%$ catalyst for the ethylic and methylic routes. This high concentration of alcohol is to guarantee a high conversion to ester. The amount of catalyst required for the transesterification reaction was determined from the acidity of soybean oil through potentiometric titration. For the transesterification process, the alkaline reagent $(\mathrm{KOH})$ was previously dissolved in the alcohol, and the soybean oil pre-heated at 
$60^{\circ} \mathrm{C}$ was added to the mixture. The solution was mixed with a magnetic stirrer at $60^{\circ} \mathrm{C}$ for $80 \mathrm{~min}$. After this period, the sample was distilled in an evaporator under reduced pressure to remove excess alcohol. The product was then placed in a funnel for $24 \mathrm{~h}$ to allow the biodiesel and glycerol phases to separate. With the biofuel separated from the glycerol, the biodiesel was washed with distilled water to remove residues from the reaction, including impurities from free fatty acids, diglycerides, triglycerides, the catalyst and residual glycerol. This process was repeated five times until the residual water remained totally transparent.

To perform mid-infrared spectroscopy on the biodiesel and oil:biodiesel blends, we prepared samples with different volumetric ratios of soybean oil (the raw material used in obtaining the ester) blended in biodiesel. Table 1 shows the proportions (in volume and percentage) of soybean oil (SO) added to methylic biodiesel (MB), ethylic biodiesel (EB), and commercial biodiesel (B). We prepared three types of blends: soybean oil in ethylic biodiesel (SOEB), soybean oil in methylic biodiesel (SOMB), and soybean oil in commercial biodiesel (SOB). The commercial biodiesel was acquired from a gas station in Dourados, Mato Grosso do Sul, Brazil.

Table 1. Biodiesel and soybean oil concentrations used to prepare the blends. In the definition of nomenclature, " $y$ " is " $M$ " for the methylic route and " $E$ " for the ethylic route. For the commercial biodiesel " $y$ " was omitted.

\begin{tabular}{ccc}
\hline $\begin{array}{c}\text { Biodiesel (B) } \\
\mathrm{mL}(\%)\end{array}$ & $\begin{array}{c}\text { Soybean oil (SO) } \\
\mathrm{mL}(\%)\end{array}$ & Nomenclature \\
\hline $5(100)$ & $0(0)$ & $\mathrm{B}$ \\
$4.95(99)$ & $0.05(1)$ & $\mathrm{SOyB}_{1}$ \\
$4.90(98)$ & $0.10(2)$ & $\mathrm{SOyB}_{2}$ \\
$4.85(97)$ & $0.15(3)$ & $\mathrm{SOyB}_{3}$ \\
$4.80(96)$ & $0.20(4)$ & $\mathrm{SOyB}_{4}$ \\
$4.75(95)$ & $0.25(5)$ & $\mathrm{SOyB}_{5}$ \\
$0(0)$ & $5(100)$ & $\mathrm{SO}$ \\
\hline
\end{tabular}

\subsection{Mid-Infrared Absorption Spectroscopy}

For infrared spectroscopy we used a Fourier Transform Spectrophotometer model Nexus 670, from Thermo Nicolet, with a frequency range between 1500 and $750 \mathrm{~cm}-1$. The samples were deposited in a cell made of $\mathrm{ZnSe}$ for attenuated total reflectance (ATR), which was coupled to the spectrophotometer. To perform the measurements we initially used $10 \mu \mathrm{L}$ of sample deposited in the ATR cell; and we 
then used $20 \mu \mathrm{L}$, and finally $30 \mu \mathrm{L}$. Thus, three spectra were determined for each sample and the simple arithmetic mean of the data was calculated. We used a resolution of $0.5 \mathrm{~cm}-1$ with 16 scans for each measurement.

\section{RESULTS AND DISCUSSION}

Figure 1 shows the mid-infrared absorption spectra obtained for the SO, EB, $M B$ and $B$ samples. In this frequency interval it is possible to note significant differences in peak positions and absorption intensities for the functional groups present in the samples. The most important absorption peaks and bands were identified, and the respective functional groups and vibrational modes are listed in Table 2. This classification is based on appropriate references (SMITH 1999, SOARES et al. 2011, SOARES et al. 2008).

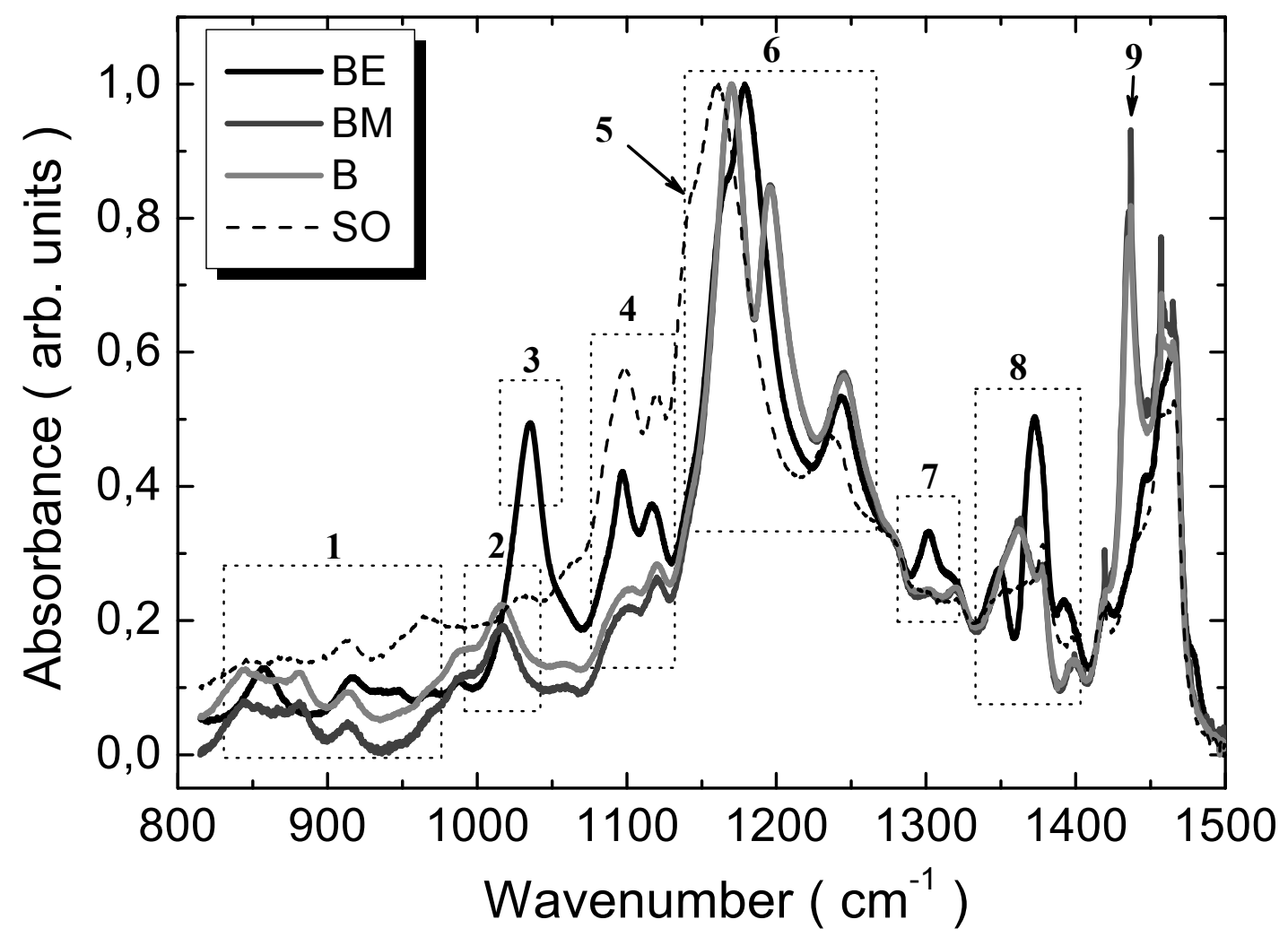

Figure 1. Absorption spectra in the fingerprint region of the samples of soybean oil (SO), ethylic biodiesel (EB), methylic biodiesel (MB) and commercial biodiesel (B). 
Table 2. Wavenumber, functional groups and vibrational modes for the main observed peaks in triglyceride and biodiesel. The samples columns are indication if the absorption intensity is weak (w) or strong (s).

\begin{tabular}{|c|c|c|c|c|c|c|}
\hline \multirow{2}{*}{$\begin{array}{l}\text { Peaks/ } \\
\text { Bands }\end{array}$} & \multirow{2}{*}{$\begin{array}{c}\text { Wavenumber } \\
\left(\mathrm{cm}^{-1}\right)\end{array}$} & \multirow{2}{*}{$\begin{array}{c}\text { Functional } \\
\text { Group }\end{array}$} & \multirow{2}{*}{$\begin{array}{c}\text { Vibrational } \\
\text { Mode }\end{array}$} & \multicolumn{3}{|c|}{ Sample } \\
\hline & & & & SO & EB & $\mathrm{MB}$ \\
\hline 1 & $845-964$ & $\mathrm{C}-\mathrm{O}-\mathrm{C}$ & Stretch & w & w & $w$ \\
\hline 2 & 1017 & $\mathrm{C}-\mathrm{O}-\mathrm{C}$ & Stretch & & & $s$ \\
\hline 3 & 1035 & $\mathrm{O}-\mathrm{C}-\mathrm{C}$ & Stretch & & $s$ & \\
\hline 4 & $1080-1130$ & C-O-C & $\begin{array}{l}\text { Asymmetric } \\
\text { Stretch }\end{array}$ & s & $\mathrm{s}$ & w \\
\hline 5 & 1143 & $\mathrm{C}-\mathrm{O}$ & $\begin{array}{l}\text { Asymmetric } \\
\text { Stretch }\end{array}$ & $\mathrm{s}$ & & \\
\hline 6 & $1161-1245$ & C-C-O & $\begin{array}{c}\text { Asymmetric } \\
\text { Stretch }\end{array}$ & & $\mathrm{s}$ & $\mathrm{s}$ \\
\hline 7 & $1302-1320$ & C-O & Stretch & & $\mathrm{s}$ & \\
\hline 8 & $1363-1378$ & $\mathrm{CH}_{3}$ & Bend & w & $s$ & w \\
\hline 9 & 1436 & $\mathrm{H}_{3} \mathrm{C}-\mathrm{O}$ & Bend & w & w & $\mathrm{s}$ \\
\hline
\end{tabular}

The chemical structures of both the triglyceride and biodiesel consist of long asymmetrical chains. The main difference is that in triglyceride there are three fatty acids chemically bonded to the glyceride, while in biodiesel the fatty acid molecule is bonded to the alcohol radical used in the reaction (KUCEK et al. 2007, TALEBIANKIAKALAIEH et al. 2013). Thus, several molecular vibrational modes belonging to the oils are also found in biodiesel, together with those due to the alcohol radical used. This can be observed in Figure 1, where both the absorption bands 1 and 4 (Table 2) correspond to the $\mathrm{C}-\mathrm{O}-\mathrm{C}$ functional group that is present in the triglyceride and biodiesel. This functional group in oil comes from the part of the molecule that has the carbonyl bonded to $\mathrm{CH}$, while in biodiesel it corresponds to the fragment of the molecule that has the carbonyl attached to the alcohol radical used in the reaction.

Peak 2 in Figure 1 corresponds to the $\mathrm{C}-\mathrm{O}-\mathrm{C}$ bond, which is present only in $\mathrm{MB}$ and $\mathrm{B}$. This functional group is derived from the $-\mathrm{OCH}_{3}$ radical of methanol, which is attached to the carbonyl group present in biodiesel. Peak 3 refers to the O-C-C bond that is present only in $\mathrm{EB}$, and is an exclusive characteristic of ethanol $\left(\mathrm{CH}_{3}{ }^{-}\right.$ 
$\mathrm{CH}_{2}$-). Peak 9 at $1436 \mathrm{~cm}^{-1}$ is characteristic of the functional group $\mathrm{H}_{3} \mathrm{C}-\mathrm{O}$ and is also exclusive to $\mathrm{MB}$ and $\mathrm{B}$. It is due to the alcohol radical used in the reaction (in this case methanol). Therefore, peaks 2, 3 and 9 can be used to indicate the route used in the biodiesel production. Here, the $B$ and $M B$ spectra were identical, which suggests that $B$ was produced by the methyl route, which is more probable since the methylic route is routinely used in Brazil.

Absorption peak 5 (Fig. 1) represents the $\mathrm{C}-\mathrm{O}$ bond, and was present only in the SO sample. Band 6 represents the $\mathrm{C}-\mathrm{C}-\mathrm{O}$ bonds, which shift in frequency from 1161 to $1245 \mathrm{~cm}^{-1}$ between the SO and EB spectra; this band arises from fatty acids that are present in both triglyceride and biodiesel. So, in the EB spectrum this absorption band can be an indication of non-transesterified oil, which is an impurity in the biofuel. The shift in frequency occurs due to the asymmetry in the chemical chains and also due to the difference in the size of the oil and biodiesel chains. The C-O bond, responsible for peak 7 in Figure 1, is present at around $1302 \mathrm{~cm}^{-1}$ in EB and at $1320 \mathrm{~cm}^{-1}$ in SO, MB and B. It differs in frequency and intensity as a consequence of the asymmetry of the chemical bonds. The same applies to absorption band 8 , which is characteristic of the $-\mathrm{CH}_{3}$ radical and is present in triglycerides and biodiesel. Furthermore, the absorption intensity in SO is lower than in biodiesel. This occurs because the biodiesel molecules have a higher concentration of this radical $\left(-\mathrm{CH}_{3}\right)$ compared with vegetable oil. This can be understood by analyzing the molecular structure before and after transesterification, as shown in Figure 2. It is apparent that the concentration of $-\mathrm{CH}_{3}$ increases after transesterification, because the concentrations of both fatty acids and the alcohol radical are higher in the biodiesel than in the oil.

a)<smiles>CC(=O)OCC(COC(C)=O)OC(C)=O</smiles><smiles>[Te][Te][Te]</smiles>
b) $3 \mathrm{H}_{3} \mathrm{C}-\mathrm{CH}_{2}-\mathrm{O}-\stackrel{\mathrm{O}}{\mathrm{C}} \ldots \mathrm{CH}_{3}$
or
c) $3 \mathrm{H}_{3} \mathrm{C}-\mathrm{O}-\stackrel{\mathrm{O}}{\mathrm{C}} \ldots \mathrm{CH}_{3}$

Figure 2. Molecular structure of triglyceride (a) ethylic ester (b) and methylic ester (c). 
INDEPENDENT JOURNAL OF MANAGEMENT \& PRODUCTION (IJM\&P)

http://www.ijmp.jor.br

v. 5, n. 1, October - January 2014.

ISSN: 2236-269X

DOI: 10.14807/ijmp.v5i1.136

In order to analyze the oil-biodiesel blends by infrared spectroscopy, we plotted the difference between the biodiesel+oil spectrum and the biodiesel spectrum. Figure 3 (a), (b) and (c) shows the curves obtained for the methylic, ethylic, and commercial biodiesel samples. In all samples, the same soybean oil was used to prepare the blend. From the observed difference, it is possible to distinguish the presence of oil in biodiesel, as noted in the region between 1050 and $1350 \mathrm{~cm}^{-1}$. Comparing the curves in Figure 3 shows that by adding oil to the biodiesel, the absorption at $1143 \mathrm{~cm}^{-1}$ due to the functional group C-O in the oil decreases, and the absorption around $1191-1196 \mathrm{~cm}^{-1}$ due to the vibration of C-C-O in biodiesel increases. This results from an apparent shift in frequency of the absorption peak in this region, which is due to the asymmetry of the molecule.

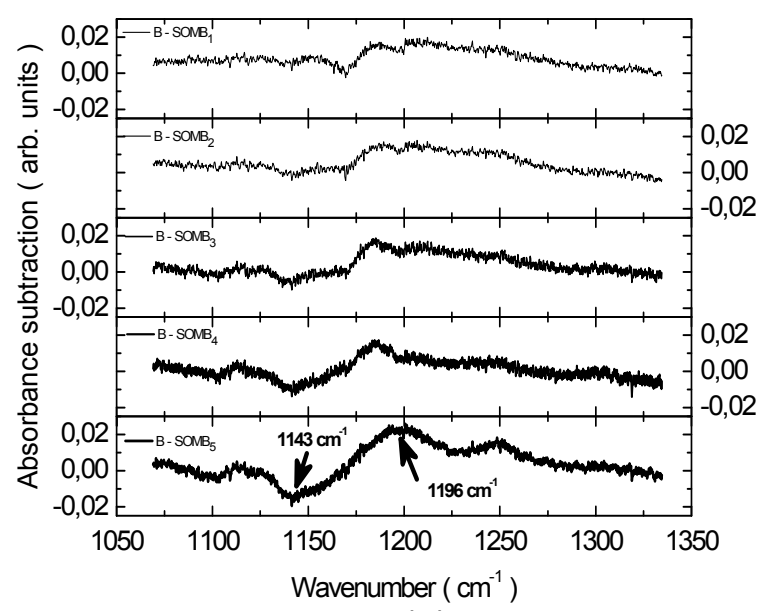

(a)

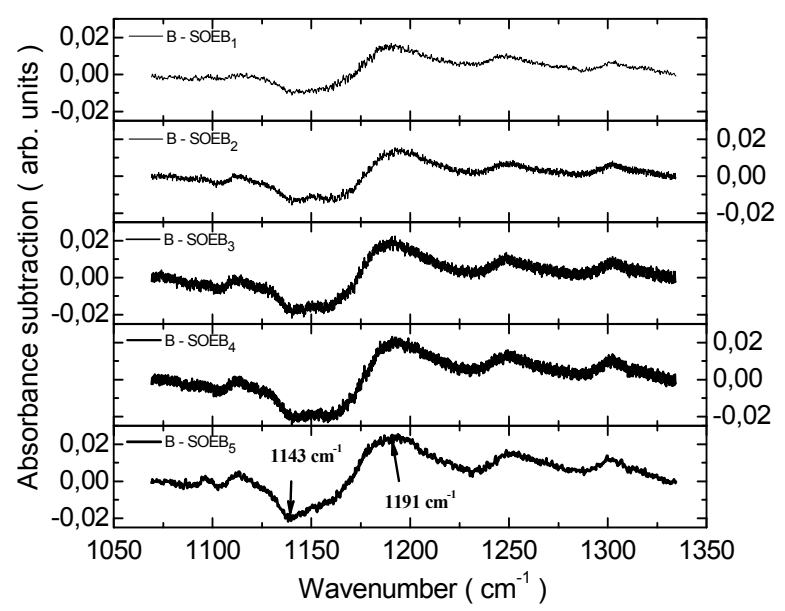

(b)

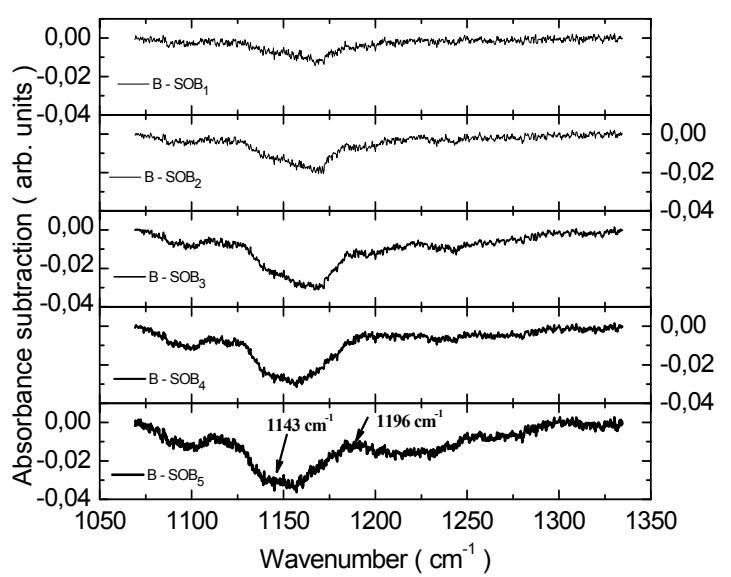

(c)

Figure 3. Absorption subtraction spectra between the biodiesel $(B)$ and the blends SOMB (a), SOEB (b) and SOB (c). 
In order to more easily visualize the results, a new plot of the relationship between the absorption intensities of greatest differences between the blends SOEB and SOMB was constructed, as shown in Figure 4. The parameter $\delta=\left[\left(I_{1096}-I_{y}\right) / I_{1096}\right] \times 100 \%$ was determined for each sample, in which $I_{1096}$ corresponds to the absorption intensity at $1096 \mathrm{~cm}^{-1}$, and $l_{y}$ represents the intensity of the absorption at $y=1017 \mathrm{~cm}^{-1}$ for MB and $y=1035 \mathrm{~cm}^{-1}$ for EB. Thus, the values of $\delta$ indicate the relative change in the absorption intensity of the blend in relation to the absorption intensity of soybean oil (impurity) at $1096 \mathrm{~cm}^{-1}$. Analysis of Fig. 4 indicates that for the SOMB blends, the $\delta$ values increased $~ 55 \%$ when only $5 \%$ soybean oil was added to the methylic biodiesel. In contrast, for blends made by the ethylic route, the $\delta$ values decreased $\sim 31 \%$ when $5 \%$ oil was added to the EB. These results indicate that the relationship used for these analyses is useful to indicate the presence of soybean oil as an impurity in biodiesel, independently of the route used to prepare the biofuel.

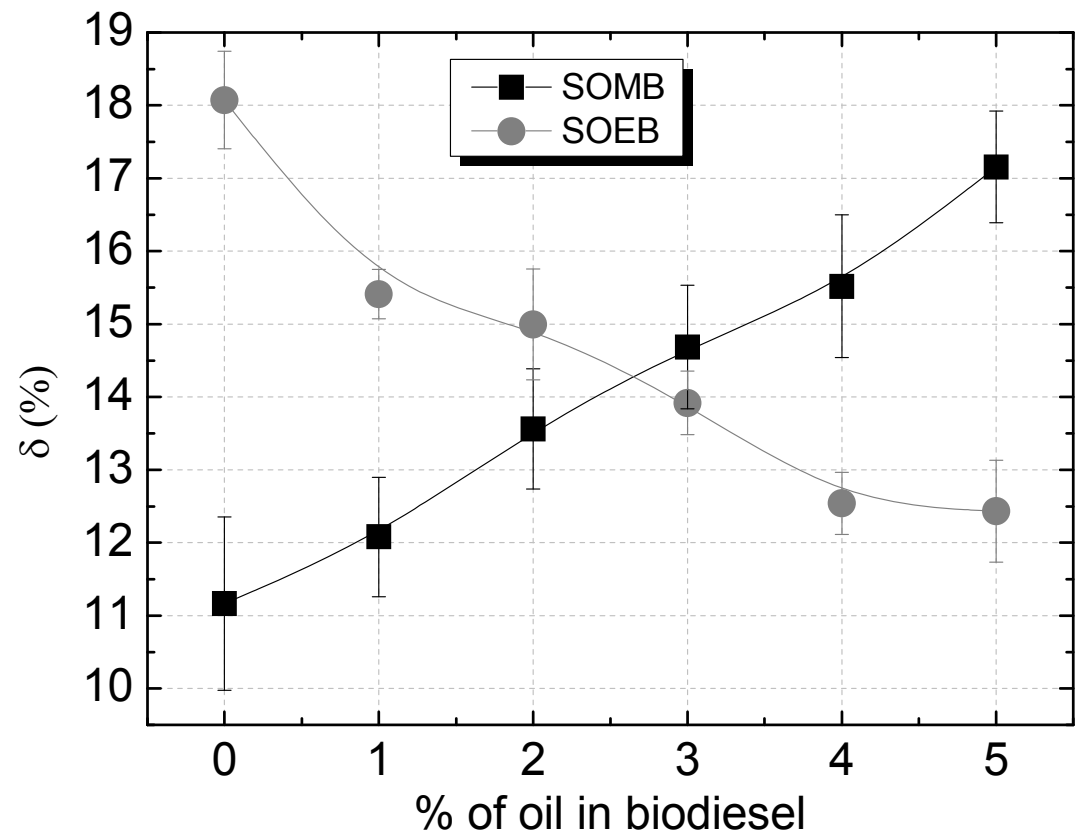

Figure 4. $\delta=\left[\left(I_{1096}-I_{y}\right) / I_{1096}\right] \times 100 \%$, with $I_{1096}$ corresponding to the absorption intensity of soybean oil and biodiesel, and $l_{y}$ representing the absorption intensity in $y$ $=1017 \mathrm{~cm}^{-1}$ for MB and $y=1035 \mathrm{~cm}^{-1}$ for EB.

\section{CONCLUSIONS}

Our results indicate that the mid-infrared spectra, specifically the vibrational modes $\mathrm{C}-\mathrm{O}, \mathrm{C}-\mathrm{O}-\mathrm{C}$ and $\mathrm{C}-\mathrm{C}-\mathrm{O}$ can provide useful information about the presence of triglycerides in biodiesel. With this method of analysis, it was also possible to assess, 
INDEPENDENT JOURNAL OF MANAGEMENT \& PRODUCTION (IJM\&P)

http://www.ijmp.jor.br

v. 5, n. 1, October - January 2014.

ISSN: 2236-269X

DOI: 10.14807/ijmp.v5i1.136

through the absorption intensities in the fingerprint region of the spectra, the route used to produce the biofuel. This study reinforces the usefulness of this method for identifying markers for impurities that may be present in blends of oil:biodiesel.

\section{ACKNOWLEDGMENTS}

The authors thank Fundect-MS, CAPES, FINEP, and CNPq for partial financial support, and the Applied Optics Group (GOA) of the Universidade Federal of Grande Dourados (UFGD) for providing the commercial biodiesel sample.

\section{REFERENCES}

ALISKE, M. A.; ZAGONEL, G. F.; COSTA, B. J.; VEIGA, W.; SAUL, C. K. (2007) Measurement of biodiesel concentration in a diesel oil mixture. Fuel, v. 86, p. 14611464.

DUBÉ, M. A.; ZHENG, S.; MCLEAN, D. D.; KATES, M. (2004) A comparison of attenuated total reflectance-FTIR spectroscopy and GPC for monitoring biodiesel production. J. Am. Oil Chem. Soc., v. 81, p. 599-603.

JIANG, S. T.; ZHANG, F. J.; PAN, L. J. (2010) Sodium phosphate as a solid catalyst for biodiesel preparation. Brazilian Journal of Chemical Engineering, v. 27, p. 137144.

KNOTHE, G. (2010) Biodiesel and renewable diesel: A comparison. Progress in Energy and Combustion Science, v. 36, p. 364-373.

KNOTHE, G.; VAN GERPEN, J.; KRAHL, J. (2005) The biodiesel handbook, AOCS Press: Illinois.

KUCEK, K. T.; OLIVEIRA, M. A. F. C.; WILHELM, H. M.; RAMOS, L. P. (2007) Ethanolysis of refined soybean oil assisted by sodium and potassium hydroxides. Journal of American Oil Chemists' Society, v. 84, p. 385-392.

LIRA, L. F. B.; ALBUQUERQUE, M. S.; PACHECO, J. G. A.; FONSECA, T. M.; CAVALCANTI, E. H. S.; STRAGEVITCH, L.; PIMENTEL, M. F. (2010) Infrared spectroscopy and multivariate calibration to monitor stability quality parameters of biodiesel. Microchemical Journal, v. 96, p. 126-131.

MEHER L. C.; SAGAR D. V.; NAIK S. N. (2006) Technical aspects of biodiesel production by transesterification - a review. Renewable and Sustainable Energy Reviewer, v. 10, p. 248-268.

MONTEIRO, M. R.; AMBROZIN, A. R. P.; LIÃO, L. M.; FERREIRA, A. G. (2008) Critical review on analytical methods for biodiesel characterization. Talanta, v. 77, p. 593.

NABI, MD. N.; AKHTER, MD. SHAMIM; SHAHADAT, M. MD. Z. (2006) Improvement of engine emissions with conventional diesel fuel and diesel-biodiesel blends. Bioresource Technology, v. 97, p. 372-378.

PIMENTEL, M. F.; RIBEIRO, G. M. G. S.; CRUZ, R. S.; STRAGEVITCH, L.; PACHECO-FILHO, J. G. A.; TEXEIRA, L. S. G. (2006) Determination of biodiesel content when blended with mineral diesel fuel using infrared spectroscopy and multivariate calibration. Microchemical Journal, v. 82, p. 201-206. 
Resolution from the Agência Nacional do Petróleo, Gás Natural e Biocombustíveis (ANP), $\quad N^{\circ} \quad 4 \quad$ from $\quad 02.02 .2010 . \quad$ See: <http://nxt.anp.gov.br/nxt/gateway.dll/leg/resolucoes_anp/2010/fevereiro/ranp\%204\% 20-\%202010.xml?f=templates $\$ f n=$ document-frame $\cdot \overline{h t} \$ 3.0 \$ q=\$ x>$.

RICHARD, R.; LI, Y.; DUBREUIL, B.; THIEBAUD-ROUX, S.; PRAT, L. (2011) On-line monitoring of the transesterification reaction between triglycerides and ethanol using near spectroscopy combined with gas chromatography. Bioresource Technology, v. 102, p. 6702- 6709.

SILVA, G. A. M.; DA RÓS, P. C. M.; SOUZA, L. T. A.; COSTA, A. P. O.; CASTRO, H. F. (2012) Physico-chemical, spectroscopical and thermal characterization of biodiesel obtained by enzymatic route as a tool to select the most efficient emmobilized lípase. Brazilian Journal of Chemical Engineering, v. 29, p. 39-47.

SILVA, T. A. R.; SANTOS, D. Q.; LIMA, A. P.; BORGES NETO, W. (2013) Model for the correction of the specific gravity of biodiesel from residual oil. Independent Journal of Management \& Production, v. 4, p. 136-147.

SMITH, B. Infrared Spectral Interpretation: A Systematic Approach. New York: CRC Press, 1999. 200p.

SOARES, I. P.; REZENDE, T. F.; SILVA, R. C.; CASTRO, E. V. R.; FORTES, I. C. P. (2008) Multivariate calibration by variable selection for blends of raw soybean oil/biodiesel from different sources using fourier transform infrared spectroscopy (FTIR) spectra data. Energy \& Fuels, v. 22(3), p. 2079-2083.

SOARES, I. P.; REZENDE, T. F.; PEREIRA, R. C C.; SANTOS, C. G.; FORTES, I. C. P. (2011) Determination of biodiesel adulteration with raw vegetable oil from ATRFTIR data using chemometric tools. J. Braz. Chem. Soc., v. 22, p. 1229-1235.

TALEBIAN-KIAKALAIEH, A.; AMIN, N. A. S.; MAZAHERI, H. (2013) A review on novel processes of biodiesel production from waste cooking oil. Applied Energy, v.104, p.683-710.

VARUN, N. K.; CHAUHAN, S. R. (2013) Performance and emission characteristics of biodiesel from different origins: A review. Renewable and Sustainable Energy Reviews, v. 21, p. 633-658. 